\title{
Analysis of Financing Dilemma of Local Government Financing Platform
}

\author{
Zefang Hu \\ Financial and Tax Department, College of Economics, Jinan University, Guangzhou, China \\ Email: zefangfang@foxmail.com
}

How to cite this paper: Hu, Z.F. (2018) Analysis of Financing Dilemma of Local Government Financing Platform. Modern Economy, 9, 1987-1997.

https://doi.org/10.4236/me.2018.912124

Received: October 22, 2018

Accepted: December 1, 2018

Published: December 4, 2018

Copyright (c) 2018 by author and Scientific Research Publishing Inc. This work is licensed under the Creative Commons Attribution International License (CC BY 4.0).

http://creativecommons.org/licenses/by/4.0/

\begin{abstract}
With the advancement of structural deleveraging and the strengthening of regulatory policies, local government financing platform is facing a certain financing dilemma. Starting from the financing dilemma of the financing platform, this paper analyzes the specific manifestations of the financing dilemma and the external and internal causes, and on this basis explores the direction of the financing platform to break the financing dilemma and carry out the market-oriented transformation. On the basis of matching local governments' financial and administrative powers, the paper holds that we should promote the separation of government and enterprises, optimize the business model and debt structure of the financing platform, promote the formation of market competitiveness of the financing platform, and become the market subject of self-management and self-responsibility for profits and losses.
\end{abstract}

\section{Keywords}

Local Financing Platform, Financing Dilemma, Transformation

\section{Introduction}

With the advancement of the structural deleveraging process and the strengthening of regulatory policies, the financing situation of local government financing platforms (hereinafter referred to as "financing platforms") are becoming more and more serious, and they are faced with certain financing difficulties, which are embodied in the increasing difficulty of financing and the superposition of existing debt due and repayment pressure. Since 2018, the default situation of financing platforms in Guizhou, Sichuan, Inner Mongolia and other places have had great impact on the market. If the external financing environ- 
ment does not improve significantly, the financing dilemma faced by financing platforms will further deteriorate. Based on this, this article analyzes the financing dilemma, faced by local financing platforms and the causes of the dilemma, and on this basis, explores the transformation direction of local government financing platforms.

Most of the previous researches have studied the financing behavior, regulatory environment and transformation issues of the financing platform from the macro level. From the perspective of the combination of macro and micro, the article obtains public data on the basis of macro analysis, and analyzes the micro-level reasons with a company as a sample. Through analysis, the financing dilemma of the financing platform mainly includes: increased financing requirements, rising financing costs, and increased debt repayment pressure. The causes of these dilemmas are not only the changes in the external environment, but also the internal reasons for the existence of the financing platform. Therefore, the financing platform needs to be transformed to achieve market-oriented operations. The specific analysis is as follows.

\section{Performance of Financing Dilemma}

With the advancement of the structural deleveraging process and the strengthening of regulatory policies, the financing situation of local government financing platforms (hereinafter referred to as "financing platforms") are becoming more and more severe, facing certain financing difficulties, mainly shown in the following aspects.

\subsection{Stricter Financing Requirements}

With the improvement and practice of the regulatory authorities on local government debt management, the financing requirements of the financing platform have been gradually increased. Not only are these requirements reflected in the subject qualification, but also in the form of debt repayment guarantee, the source of debt repayment funds and the legal compliance of financing documents.

From the perspective of the subject qualification, the regulatory authorities have gradually increased the asset quality requirements of financing platforms. Before 2010, financing platforms can expand their asset scale by increasing public welfare assets. Subsequently, the public welfare assets were tightened, and mainly focused on the land purchase and storage; In 2013, the management and control was further upgraded, and the financing platforms had to increase the allocation and transfer of land to increase the asset scale. At this stage, under the centralized management of the NDRC (the National Development and Reform Commission), the verification of effective net assets of the enterprise bond declaration is getting stricter and stricter.

At the same time, on the one hand, the local government's credit support that financing platforms rely on for development is being gradually divested, making 
the financing of financing platforms more and more difficult. On the other hand, it also brings certain risks to local governments and related platforms. This makes the financing platform need to seek more effective measures to ensure the repayment of debt. On July 18, 2018, the Ministry of Finance issued four consecutive circulars to announce the accountability cases of illegal government debt guarantees in Yunnan, Guangxi, Anhui, Ningbo, and other places [1] [2] [3] [4]. These cases involved the issuing of resolutions by the Standing Committee of the Local People's Congress, which promised to include the debating funds into the local fiscal and public budget, and fully repay the principal and interest of loans on time. The four announcements show that the financial authorities are gradually stripping out the credit support of local governments and controlling the expansion of local government debt scale.

\subsection{Higher Financing Costs}

With the strengthening of financial supervision, the financing cost of local government financing platforms is also gradually increasing. Taking the yield to maturity of urban investment bonds as an example, since November 2016, the yield to maturity of urban investment bonds has gradually increased, and the financing cost of the financing platform has increased, as shown in Figure 1 .

Seen from Figure 1, the yield to maturity of urban investment bonds is at a high level since 2018. At the same time, there are also financing costs of channels not reflected in the figure, such as financial leasing and trust, and the financing costs of these channels have also increased to some extent.

\subsection{Huger Repayment Pressure}

Faced with ever-strengthening financing requirements and increasing financing costs, as well as market funding constraints, the situation of financing platforms has become increasingly troublesome, and debt repayment pressure has increased, since 2018. Taking the corporate bonds as an example, the total issuance amount is far less than the total repayment amount in the market, as shown in Figure 2.

From Figure 2, we can see the change trend of total issuance and total repayment of the corporate bonds during recent years. Due debt repayment of financing platforms is under great pressure. If it cannot be raised in time, the risk of default will occur.

\section{Reason of Financing Dilemma}

There are many reasons for the financing dilemma, including the change of external environment, as well as the existence of the financing platform itself. The internal and external factors have jointly contributed to the financing dilemma. 


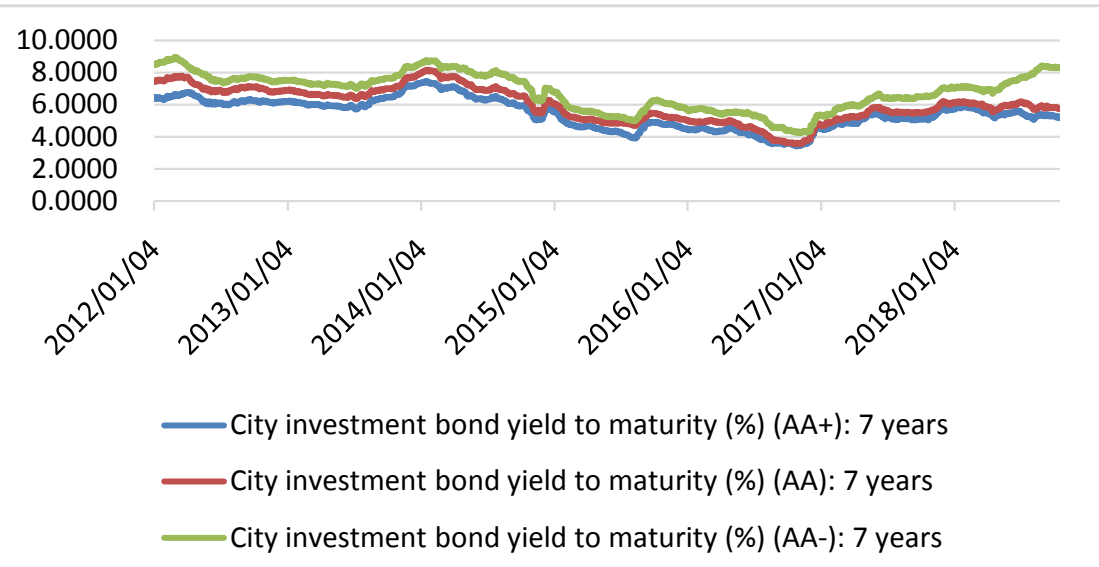

Figure 1. City investment bond yield to maturity of different Rating body. Source: Wind.

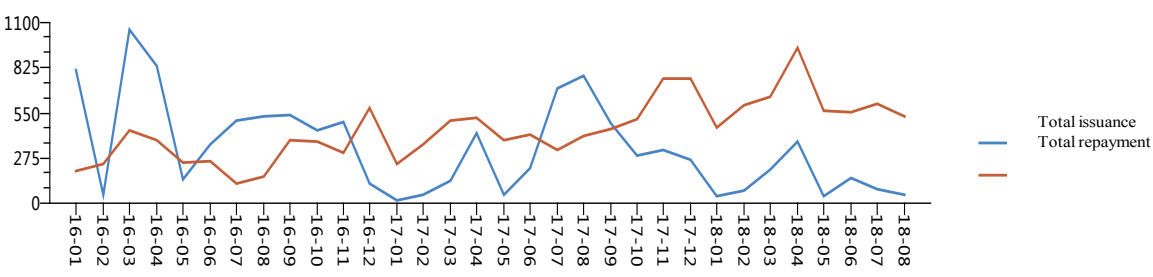

Figure 2. Thetotal issuance amount and the total repayment amount in the market. Source: Wind.

\subsection{External Conditions}

In terms of changes external factors, mainly due to the tightening of the control of local government debt by the financial authorities and the strengthening of financial supervision by the financial regulatory authorities, the two sides constitute a change in the external financing conditions of the financing platform, while the long-term mismatch between financial power and authority is also an important external cause.

\subsubsection{Stricter Control of Local Government Debt}

In recent years, the main provisions in the documents concerning the local government and the financing platforms issued by the State Council and relevant ministries are as follows.

Seen from Table 1, with the tightening of local government debt control by relevant departments, the local government credit background of the financing platform began to gradually detach, and the financing condition gradually deteriorated, leading to the financing dilemma.

\subsubsection{Tightening Market Funds}

With the introduction of the new regulations on capital control and the implementation of a series of other financial regulatory policies, including the gradual advancement of de-leveraging, the market capital has gradually tightened, which not only increases the financing costs, but also makes the financing more difficult. 
Table 1. Summary of regulatory policies. Source: open data collation.

\begin{tabular}{|c|c|c|c|c|}
\hline & Documents & Time & Department & Essential Points \\
\hline 1 & $\begin{array}{l}\text { 《The People's Republic of China } \\
\text { Budget Law》 }\end{array}$ & $\begin{array}{c}\text { Revised August } \\
31,2014\end{array}$ & The State Council & $\begin{array}{l}\text { Local governments and their affiliated departments } \\
\text { must not irregulate the debt. }\end{array}$ \\
\hline 2 & $\begin{array}{l}\text { 《Notice on Stopping Illegal Financing } \\
\text { by Local Governments》 (Fiscal [2012] } \\
\text { no. 463) [6] }\end{array}$ & $\begin{array}{l}\text { December 24, } \\
\quad 2012\end{array}$ & $\begin{array}{l}\text { The ministry of } \\
\text { Finance, NDRC } \\
\text { the People's Bank } \\
\text { of China, CBRC }{ }^{2}\end{array}$ & $\begin{array}{l}\text { Strictly forbidden to directly or indirectly absorb public } \\
\text { funds and raise funds. } \\
\text { Effectively regulate local governments to borrow } \\
\text { government debts by way of repurchase. } \\
\text { Resolutely stop local governments from illegally } \\
\text { undertaking guarantees. }\end{array}$ \\
\hline & & & & $\begin{array}{l}\text { Establish and standardize local government debt } \\
\text { financing mechanism. }\end{array}$ \\
\hline 3 & $\begin{array}{l}\text { 《State Council on Strengthening Local } \\
\text { Government Debt Management } \\
\text { Advice》 }\end{array}$ & $\begin{array}{l}\text { September 21, } \\
2014\end{array}$ & The State Council & $\begin{array}{l}\text { Prohibit the new government debt. } \\
\text { Standardize capital injection, subsidy behaviors, and } \\
\text { prohibit illegal guarantees. }\end{array}$ \\
\hline & & & & Stock debt screening and control. \\
\hline 4 & $\begin{array}{l}\text { 《Notice on Further Regulating Local } \\
\text { Government's Debt Financing } \\
\text { Behavior》 }\end{array}$ & April 26, 2017 & $\begin{array}{l}\text { The ministry of } \\
\text { Finance, NDRC } \\
\text { the People's Bank } \\
\text { of China, CBRC }\end{array}$ & $\begin{array}{l}\text { Clean up and rectify the government's illegal } \\
\text { guarantees. } \\
\text { Standardize the financing behavior of platform } \\
\text { companies. }\end{array}$ \\
\hline 5 & $\begin{array}{l}\text { 《Notice on Resolutely Stopping Local } \\
\text { Illegal Financing in the Name of } \\
\text { Government Procurement Services》 } \\
\text { [9] }\end{array}$ & May 28, 2017 & $\begin{array}{l}\text { The ministry of } \\
\text { Finance }\end{array}$ & Standardize government purchase services. \\
\hline 6 & $\begin{array}{l}\text { 《Notice of the Ministry of Finance on } \\
\text { Doing a Good Job of Local } \\
\text { Government Debt Management in } \\
2018 》[10]\end{array}$ & $\begin{array}{l}\text { February } 24, \\
\quad 2018\end{array}$ & $\begin{array}{l}\text { The ministry of } \\
\text { Finance }\end{array}$ & $\begin{array}{l}\text { Accelerate the progress of local government debt } \\
\text { replacement. }\end{array}$ \\
\hline
\end{tabular}

Take the Shanghai Interbank Offered Rate (SHIBOR (\%): 1 week) as an example. The trend is as follows.

Judging from Figure 3, with the strengthening of financial supervision and the gradual advancement of de-leveraging, the market capital have tightened, which has caused the financing dilemma of financing platforms to a certain extent.

\subsubsection{Mismatch between Financial and Administrative Power}

In the external condition, the mismatch between financial and administrative power is another important reason for the financing dilemma of financing platforms. Generally speaking, due to the incomplete and imperfect reform of the tax-sharing system, China's central government and local governments do not match the division of financial and administrative power. The local governments have assumed more responsibility for expenditure, while the corresponding financial rights do not match. Since the reform of the tax-sharing system, the

\footnotetext{
${ }^{1}$ National Development and Reform Commission.

${ }^{2}$ The China Banking Regulatory Commission.

${ }^{3}$ National Development and Reform Commission.

${ }^{4}$ The China Banking Regulatory Commission.
} 


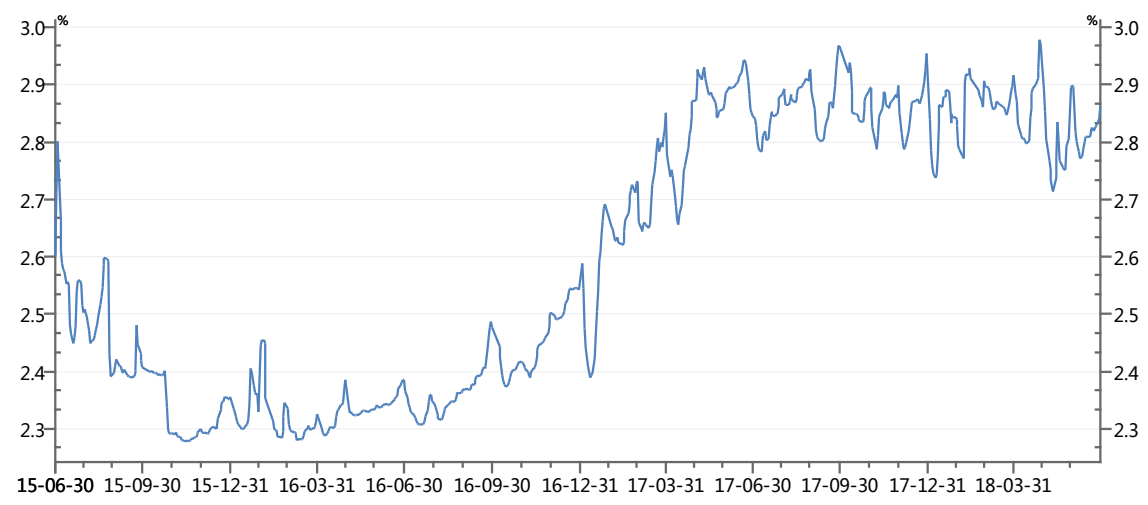

Figure 3. Shanghai Interbank Offered Rate (SHIBOR (\%): 1 week). Source: Wind.

trend of the distribution of financial and administrative power between China's central and local governments has shown the following trends.

From Figure 4, the local government has assumed the expenditure responsibility far beyond the proportion of its income in the case of obtaining a similar proportion of the fiscal revenue to the central government. Excluding the central government transfer payments to the local, the local governments still bear more responsibility for expenditure. The mismatch between financial and administrative power has contributed to the development of the financing platform to a certain extent. As a result, the financing platform has assumed the role of financing for local governments at the beginning of its birth, and has transferred part of the responsibility of local governments.

Against the background of the mismatch between financial and administrative power, the financing platform has accumulated a considerable amount of debt while taking the expenditure responsibility. At the same time, new financing channels must be developed to meet new funding needs. Faced with the continuous strengthening of local government debt control and financial supervision, the financing dilemma of the financing platform is further stressed. The mismatch between financial and administrative power has further worsened the financing condition of the financing platform.

In summary, the financing platform faces the strict control of local government debt and the tight supervision of financial regulatory authorities in the context of long-term mismatch between local government financial and administrative power. The difficulty and the cost of financing has also aggravated, thus the financing dilemma faced by the financing platform has a certain external attack.

\subsection{Internal Conditions}

The ever-changing external condition is an important factors for the current financing difficulties of the financing platform. The financing platform itself has many problems. Therefore, when the external condition changes, it cannot respond in a timely and effective manner, and financing activities are blocked. Specifically, the financing difficulties faced by the financing platform are mainly 


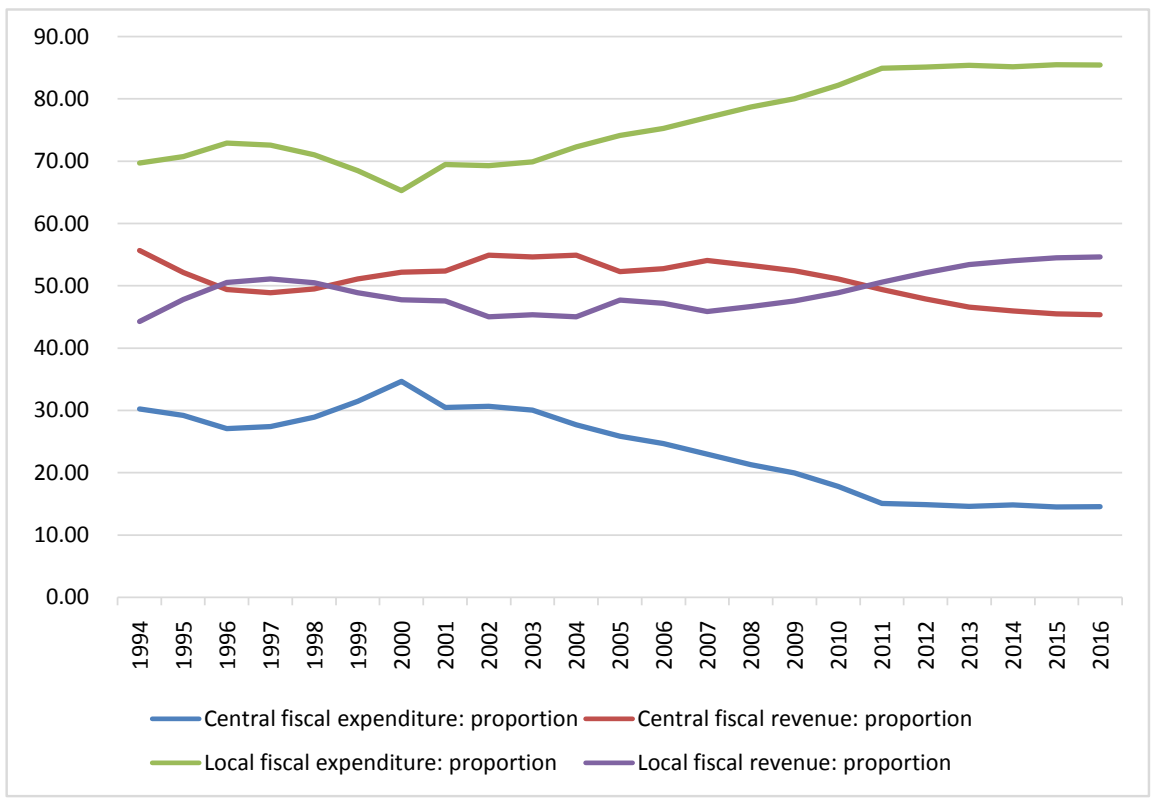

Figure 4. The distribution of revenue and expenditure rights between central and local. Source: Wind.

due to the following three reasons: First, the asset scale of the financing platform depends on the government's capital injection and land assets, the liquidity and the quality of the assets is poor. Second, the financing platform's business is mainly engineering agent business. The agency construction business is mainly based on a single mode, which is difficult to form a positive net cash flow from operating activities. Third, the debt platform has a higher level of debt, and cash inflows are more dependent on fundraising activities. The debt does not match its own production and operation activities. In the event that the activity cannot obtain positive cash inflows, the pressure on its repayment is exacerbated. In order to discuss these intrinsic reasons in more details, the article selects the Company A that has publicly issued corporate bonds in the market in 2018 as a sample and obtains corresponding public information [11], based on this, analyzing the existing problems of the financing platform.

\subsubsection{Poorer Asset Quality}

From the audit report of Company, although the scale of assets is large, the quality of its assets is relatively low, mainly due to the excessive reliance on land assets and government capital injection. Moreover, the inventory of liquid assets (mainly land assets, commissioned construction projects and land consolidation costs) has poor liquidity, which affects the liquidity of assets.

At the end of 2015, the end of 2016 and the end of 2017, the total assets of Company A were respectively 745766.11 million yuan, 1401130.42 million yuan and 1669320.46 million yuan, and the net assets were respectively 477147146756.5 million yuan and 7173140.8 million yuan. In the past three years, largely supported by the county government, Company A whose net assets increased by a large margin. In 2015, 2016 and 2017, the county government poured monetary 
funds, land and other assets to the company, and increased the company's capital reserve by $41,153,800$ yuan, $159,805,053$ yuan and 345550.00 yuan, respectively.

At the end of 2015 to 2017, the inventory of Company A was 513782.94 million yuan, 657356.44 million yuan and 8898408.9 million yuan respectively, accounting for $68.89 \%$ and $46.92 \%$ and $53.31 \%$ of the total assets of Company A respectively. Up to December 31, 2017, the construction cost the land use right amounted to 449.40 million yuan, the company's construction project amount was $125,929,500$ yuan, and the company's land consolidation cost was $2,881,994,400$ yuan.

From the relevant financial data of Company A, the asset scale is extremely dependent on land assets, and a large part of these land assets are assessed and recorded in the account. The lower asset quality and the higher the land assets make the liquidity of the assets poor. At the same time, the company's inventory balance at the end of 2017 has a large part of the construction project and land consolidation costs; these are also closely related to local governments. Overall, the asset quality of Company $\mathrm{A}$ is poor.

\subsubsection{Single Business Model}

From the perspective of Company A's business model, its business model is relatively simple, mainly consisting of engineering construction business, and relies heavily on local governments.

From 2015 to 2017, the operating income of Company A mainly came from engineering construction income, which in the past three years was 57343.88 million, 32336.03 million and 78,04591 million respectively, accounting for $99.03 \%, 43.10 \%$ and $82.30 \%$ of the operating income respectively. Company A's engineering construction business model is as follows: Company A raises project construction funds first, and is responsible for the whole process construction of the project, including pre-design, construction, project completion settlement, completion acceptance, post-project evaluation and other work related to project construction. The investment of Company A to undertake the construction project is included in the construction cost. After the project is qualified, the Company A will settle with the relevant departments of the county people's government. The county finance bureau shall pay $15 \%$ of the agency construction cost in accordance with the cost of all the construction costs incurred by the Company A.

From the data point of view, Company A's business model relies more on engineering and construction business, and its business model is relatively simple. It relies heavily on local governments and also bears part of the local government's expenditure responsibility. From 2015 to 2017, the net cash flow from operating activities of Company A was 33870.23 million yuan and -229582.45 million yuan and -127867.69 million yuan, respectively. The single business model makes its net cash flow from operating activities negative, which cannot effectively support its long-term development and restricts its ability to finance in the capital market. 


\subsubsection{Heavily in Debt}

Relying on the local government credit background, the financing platforms have made outstanding contributions to the development of the local economy in the past few years. At the same time, it is also indebted.

From the perspective of Company A, up to December 31, 2017, the audited consolidated assets totaled 16.693 billion yuan, total liabilities were 9.520 billion yuan, asset-liability ratio was $57.03 \%$, and asset-liability ratio was at a relatively high level. In 2017, the net cash flow from operating activities of Company A was -12.79 million yuan, the net cash flow from investing activities was -0.44 billion yuan, and the net cash flow from financing activities was 2.030 billion yuan. In terms of cash flow, Company A It also relies more on the cash flow generated by fundraising activities. This also shows that A company's cash flow is not good. A single local government-dependent business model cannot generate positive cash flow. It can only rely on continuous financing activities to maintain its production and operation activities.

The high level of debt makes company a face greater repayment pressure. Especially, if the financing channel is blocked or the new cash inflow of financing activities cannot be obtained, the debt repayment of Company A will be damaged, to some extent, and may even lead to the breach of contract.

In summary, from the perspective of Company A, low asset quality, single business model and heavy liabilities are the internal reasons for financing difficulties. Company A is a microcosm of many financing platforms in China; there are many internal reasons for the financing difficulties faced by financing platforms.

\section{The Transformation Direction of Financing Platform}

Faced with the constant changes of the external condition and its own shortcomings, transformation is the future development direction of the financing platform. From a macro perspective, it is necessary to take the principle of marketization as a guide, rationalize the relationship with the government, find a correct position, develop a diversified business model, and form its own market competitiveness. In terms of operation, it is necessary to promote the separation of government and enterprises, optimize business models and the debt structure, and promote the tax-sharing reform to rationalize financial rights and powers.

\subsection{Separate Government Administration and Enterprise Management}

At this stage, the financing platforms, whether from the composition of assets or the development of business, have a great relationship with local governments. According to the principles of marketization, they have not separated.

Therefore, the first step in the transformation of the financing platform is to promote the separation of government and enterprises, give full play to the role of the market, rationalize the relationship between the financing platform and the local government, and make the financing platform a market entity that is 
self-employed and self-financing. On the one hand, the financing platform can enhance its competitiveness in the market competition. On the other hand, it can also rationalize the functions of the financing platform and become the operational body in the market.

\subsection{Optimize Business Model}

From the business perspective, the only way to transform and upgrade financing platforms is to optimize the business model to form positive net cash flow of business activities. Therefore, we must get rid of the single-dependent model, develop in a diversified way to form the core competitiveness.

\subsection{Optimize the Debt Structure}

From the perspective of the scale and structure of the debt, the current level of the platform is high, and the structure of liabilities is not reasonable. Therefore, it is necessary to optimize the debt structure, control the scale of debt, and adapt the scale and structure to its own production and operation to prevent financial risks.

\subsection{Promote the Tax-Sharing Reform to Rationalize Financial and Administrative Powers}

The matching of financial and administrative power is the fundamental way to solve the financing dilemma and promote the upgrading of financing platform. The local government's financial and administrative power are matched to reduce the local government's spending pressure, reducing the direct or indirect debt burden, thus promoting the financing platform separate from the government and more market-oriented.

From the perspective of the transformation of financing platforms, the most important is to promote the market-oriented, mainly including promoting the separation of government and enterprises, optimizing business models and the debt structure, promoting the reform of tax sharing system. In the process of transformation and upgrading, improve the quality of its assets, optimize its business model, and form a healthy and reasonable cash flow of positive business activities to form its own market competitiveness.

\section{The Conclusion}

Based on the financing dilemma faced by the financing platform, this paper analyzes the specific performance of the financing difficulties, the external and internal reasons, and probes into the transformation direction of the financing platform. The paper believes that there are some external factors in financing dilemma of the financing platform, but there are also some internal reasons, such as, poor asset quality itself, the single business model, and heavy liabilities burden. Therefore, it is necessary to carry out market-oriented transformation to develop and enhance itself so as to get rid of the financing dilemma. 


\section{Conflicts of Interest}

The author declares no conflicts of interest regarding the publication of this paper.

\section{References}

[1] Anhui Province Legally Blames Individual Regions for Illegally Borrowing in the Name of Purchasing Services Strictly Regulate Government Debt. http://yss.mof.gov.cn/zhuantilanmu/dfzgl/ccwz/201807/t20180717_2963095.html

[2] Ningbo City, According to Law, Investigate the Illegal Use of BT in Various Areas to Prevent Debts and Financial Problems. http://yss.mof.gov.cn/zhuantilanmu/dfzgl/ccwz/201807/t20180717_2963100.html

[3] Yunnan Province Accountability Handling Some Municipalities and Counties Passing Trust Products Violating Laws and Regulations. http://yss.mof.gov.cn/zhuantilanmu/dfzgl/ccwz/201807/t20180717_2963202.html

[4] The Autonomous Region of Guangxi Autonomous Region Deals with the Problem of Illegal and Illegal Debt Guarantee in Some Areas. http://yss.mof.gov.cn/zhuantilanmu/dfzgl/ccwz/201807/t20180717_2963299.html

[5] The People's Republic of China Budget Law. http://www.mof.gov.cn/mofhome/jiandujianchaju/zhengwuxinxi/faguizhidu/20150 9/t20150908_1452983.html

[6] Notice on Stopping Illegal Financing by Local Governments. http://www.gov.cn/gzdt/2012-12/31/content_2302905.htm

[7] State Council on Strengthening Local Government Debt Management Advice. http://www.gov.cn/zhengce/content/2014-10/02/content_9111.htm

[8] Notice on Further Regulating Local Government's Debt Financing Behavior. http://yss.mof.gov.cn/zhengwuxinxi/zhengceguizhang/201706/t20170602_2614514. $\underline{\mathrm{html}}$

[9] Notice on Resolutely Stopping Local Illegal Financing in the Name of Government Procurement Services.

http://yss.mof.gov.cn/zhuantilanmu/dfzgl/zcfg/201803/t20180326_2851243.html

[10] Notice of the Ministry of Finance on Doing a Good Job of Local Government Debt Management in 2018.

http://yss.mof.gov.cn/zhuantilanmu/dfzgl/zcfg/201705/t20170503_2592801.html

[11] China Bond Information Network. http://www.chinabond.com.cn/d2s/index.html 